DOI: $\underline{\text { https://doi.org/10.24867/12GI13Antonic }}$

\title{
ANALIZA RAZVIJENOSTI TRŽIŠTA OSIGURANJA U REPUBLICI SRBIJI SA POSEBNIM OSVRTOM NA OSIGURANJE OD ODGOVORNOSTI
}

\section{ANALYSIS OF THE INSURANCE MARKET IN REPUBLIC OF SERBIA WITH SPECIAL REFERENCE TO LIABILITY OF INSURANCE}

\author{
Momčilo Antonić, Fakultet tehničkih nauka, Novi Sad
}

\begin{abstract}
Oblast - INŽENJERSKI MENADŽMENT
Kratak sadržaj - U ovom radu su prikazane teorijske $i$ metodološke osnove osiguranja, a sa posebnim osvrtom na osiguranje od odgovornosti. Pored toga, predstavljene su $i$ osnovne podele osiguranja $i$ osnovni pojmovi značajni u osiguranju. Predstavljena je analiza razvijenosti tržišta osiguranja u Republici Srbiji sa osvrtom na osiguranje od odgovornosti. Data je komparativna analiza sa tržištem osiguranja u razvijenim zemljama.
\end{abstract}

Ključne reči: Osiguranje, tržište osiguranja, osiguranje od odgovornosti

\begin{abstract}
This paper presents the theoretical and methodological foundations of insurance, with special reference to liability insurance. In addition, the basic divisions of insurance and basic concepts important in insurance are presented. An analysis of the development of the insurance market in the Republic of Serbia is presented with a review of liability insurance. A comparative analysis with the insurance market in developed countries is given.
\end{abstract}

Keywords: Insurance, insurance market, liability insurance

\section{UVOD}

Osiguranje se na različite načine može pojaviti u brojim aspektima našeg svakodnevnog života. Razlog za to je, prije svega, što je svako od nas kao pojedinac na dnevnom nivou izložen različitim oblicima opasnosti koje mogu da dovedu do toga da se prouzrokuju štete.

Osiguranje je izuzetno široka teorijska oblast iz prostog razloga što postoji veliki broj različitih vrsta osiguranja. Iz navedenog razloga su kreirane određene podjele osiguranja, gde su one najvažnije orijentisane na to koji tip osiguranog slučaja dato osiguranje treba da pokrije. U ovom master radu će biti predstavljena teorija osiguranja sa njegovim osnovnim karakteristikama, zatim osnovne vrste osiguranja, i na kraju će se fokus staviti na jednu od grupa iz navedene podjele, a to je osiguranje od odgovornosti kom će biti posvećena posebna pažnja.

\section{NAPOMENA:}

Ovaj rad proistekao je iz master rada čiji mentor je bio dr Đorđe Ćosić, vanr. prof.

\section{OSIGURANJE I NJEGOVE OSNOVNE KARAKTERISTIKE}

Osiguranje predstavlja oblast od posebnog društvenog i ekonomskog interesa, a samo sprovođenje osiguranja podrazumijeva specifičnu ekonomiku. „Sama riječ osiguranje, u svom etimološkom smislu, ukazuje da je riječ o specifičnoj vrsti zaštite, obezbjeđenja, povjerenja u nešto i sigurnosti [1]. Pojmovi opasnost, rizik, šteta, odšteta, usko su povezani s pojmom osiguranja, a sam naziv osiguranje treba da stvori predstavu o sigurnosti.

\subsection{Istorijat osiguranja}

Način transporta i skladištenja različitih sirovina ili robe je u davnim razdobljima istorije vršen na, kao što nam je svima poznato, dosta primitivnije načine. Na primjer, roba je preko rijeka prevožena splavovima ili čamcima, a skladišni prostori nisu imali bezbjednosne sisteme koji su poznati danas. Sve ovo je često dovodilo do toga da se kvalitet sirovina $\mathrm{i}$ robe gubio $\mathrm{u}$ velikoj mjeri ili da je dolazilo do njihovog potpunog uništenja.

Česti gubici su navodili ljude na to da razmišljaju o preduzimanju određenih mjera kako bi se ublažile posledice ovakvih događaja. Mjere koje su tada preduzimane su najčešće imale preventivni karakter, kao što je bolje upravljanje sirovinama i robom ili prilagođavanje uslova njihovog čuvanja. $\mathrm{Na}$ primer, provjeravan je precizan kapacitet čamaca za prevoz robe kako bi se spriječilo njihovo potapanje u rijeci. Ovo su prvi koraci koji su predstavljali raspodjelu rizika i doveli do dalje do razvoja ove oblasti.

Korjene osiguranja koje je funkcionisalo po sličnom principu koji nam je danas poznat moguće je pronaći kod Vavilonaca. Osiguranje koje je tada sprovođeno tako što je registrovanim vlasnicima određenog imetka usljed nastanka neželjenog događaja isplaćivana naknada štete.

Od druge polovine 19. vjeka počinje najvažniji period u razvoju osiguranja. U ovom momentu država nastupa na scenu osiguranja nakon što je uočila njegov ekonomski i socijalni značaj. Država je uočila ovu pogodnost kada je ustanovljeno da se kapital pojedinaca zadržava $u$ osiguravajućim kućama dug vremenski period. Dakle, fond jednog osiguravajućeg društva može da predstavlja značajan izvor sredstava za državni fond.

Kada govorimo o razvoju osiguranja na teritoriji Republike Srbije, njegovi prvi tragovi se mogu pornaći u Zakoniku cara Dušana iz 1349. godine i 1354. godine. 
Međutim, osiguranje u svom modernom obliku se pak javlja, kao privredna akrivnost, sredinom 19. veka.

\subsection{Pojam osiguranja}

Osiguranje je specifična privredna djelatnost koju obavljaju posebni privredni subjekti, društva za osiguranje, radi pružanja materijalne zaštite fizičkim i pravnim licima od posledica osiguranih rizika na osnovu primjene posebnih pravnih pravila i pravila tehnike osiguranja zasnovane na statistici i matematici [2].

Definicija osiguranja prema „Zakonu o obligacijama“ glasi: „Ugovorom o osiguranju obavezuje se ugovarač osiguranja da plati odredjeni iznos organizaciji za osiguranje (osiguravač), a organizacija se obavezuje da, ako se desi osigurani dogadjaj, koji predstavlja osigurani slučaj, isplati osiguraniku ili nekom trećem licu naknadu, odnosno ugovorenu svotu ili učini nešto drugo.“

Važan pojam koji je već nekoliko puta spomenut, a čija je važnost u ovoj definiciji posebno istaknuta, jeste ugovor o osiguranju. Ovaj dokument mora da sadrži određene elemente kako bi se smatrao validnim, a ti elementi su propisani zakonom. Pored toga, pri sklapanju ugovora se moraju poštovati određeni principi.

\subsection{Funkcije osiguranja}

Osiguranje, kao važna djelatnost bez koje se danas teško može zamisliti obavljanje najvećeg broja radnji/djelatnosti u svakodnevnom životu, donosi višestruke koristi. $\mathrm{Na}$ koji to način osiguranje direktno doprinosi unapređenju našeg života se može lako prikazati kroz njegove funkcije. Postoje tri osnovne funkcije osiguranja koje se smatraju najvažnijim, a to su:

1. Funkcija zaštite imovine i lica;

2. Finansijska funkcija;

3. Socijalna funkcija [3].

Funkcija zaštite imovine i lica je prva poznata funkcija osiguranja koja je, u suštini, i inicirala nastanak ove oblasti u obliku u kom je danas poznajemo. Ono što je za ovu funkciju osiguranja važno reći je da se zaštita imovine i lica može obavljati na dva načina- posredno i neposredno. Posredan način zaštite imovine i lica se ostvaruje u momentu kada nastupi osigurani slučaj. Neposredno čuvanje imovine i lica sprečava nastanak štete, doprinosi umanjivanju već nastale štete i motiviše osiguranike da samostalno štite svoju imovinu na efikasniji način.

Finansijska funkcija, koja se još naziva i funkcijom mobilizacije novčanih sredstava, proizilazi iz pravila da se premije osiguranja plaćaju unaprijed. Pošto se naknada štete vrši tokom godine kada nastane šteta, do tog momenta prikupljena sredstva se mogu koristiti na određene isplative načine. Drugim riječima, prikupljenim sredstvima se može upravljati na takav način da se ostvaruje profit koji će biti u funkciji osiguravajućeg fonda, povećanja rezervi sigurnosti i u krajnjem slučaju, ostvarenja profita samog osiguravajućeg društva.

Socijalna funkcija osiguranja se ogleda kroz ekonomsku zaštitu čoveka i njegove imovine koja može biti oštećena ili uništena usled određenih rizičnih situacija, djelovanjem različitih opasnosti.

\subsection{Veza rizika i osiguranja}

Pojam rizika ima različita značenja. „No rizik je, pre svega, stanje neizvesnosti, odnosno on predstavlja budući neizvestan događaj čijim ostvarenjem može nastati šteta ili korist [4]. Pojedini autori kažu da je rizik opasnost od nastanka privredno ili društveno štetnog događaja koji podrazumeva obavezu osiguravača da plati usmu osiguranja. Postoji razlika između privredne i društvene štetnosti. „Dakle, privredna štetnost je prisutna kod neživotnih osiguranja, dok je društvena štetnost prisutna kod životnih osiguranja [5]. Granica između ove dvije vrste štetnosti je tanka, pa je teško na ovaj način definisati njihovo prisustvo $\mathrm{u}$ navedene dvije grupe osiguranja. Njihova identifikacija se mora vršiti sa više različitih aspekata. Navedeni okvir uzima u obzir samo širu sliku posmatranja.

Rizik se može posmatrati sa dva stanovišta, a to su:

- Stanovište osiguranika;

- Stanovište osiguravača- osiguravajućeg društva.

Kadase rizik posmatra iz ugla osiguranika, na prvom mestu se nalazi njegova potreba za zaštitom od ostvarenja rizika. Sa aspekta osiguravača se govori o delatnosti osiguranja, odnosno o svrsi postojanja osiguranja kao delatnosti.

\subsection{Subjekti u osiguranju i njegovi osnovni elementi}

Osnovna dva subjekta u procesu osiguranja su:

1. Osiguravač;

2. Osiguranik.

Pored ova dva subjekta veoma važnu ulogu imaju i sledeći:

1. Korisnik osiguranja;

2. Ugovarač osiguranja.

Svaki od navedenih subjekata na određeni način učestvuje u procesu osiguranja i doprinosi njegovoj uspešnoj realizaciji. Osiguravač je pravno lice koje na sebe preuzima rizik zbog oštećenja ili uništenja stvari, kao i rizik prijevremene smrti kod osiguranja lica i druge rizike od pravnog ili fizičkog lica koje je izloženo tim rizicima. Osiguranik se može javiti kao pravno lice ili kao fizičko lice. Lice koje zaključi ugovor o osiguranju za svoje ime i svoj račun naziva se osiguranikom. Ugovarač osiguranja je lice (pravno ili fizičko) koje ima imovinski interes nad stvarima koje su predmet osiguranja, te na osnovu toga stiče pravo ugovaranja osiguranja. Korisnik osiguranja je lice kome je osiguravač u obavezi da isplati naknadu iz osiguranja kad nastupi osigurani slučaj. Korisnik osiguranja može biti i osiguranik (kao što je napomenuto), ali može biti i drugo lice.

Osnovni elementi osiguranja su:

1. Rizik;

2. Premija osiguranja;

3. Osigurani slučaj;

4. Suma osiguranja;

5. Fondovi osiguranja [6].

Navedeni elementi osiguranja se primenjuju u procesu osiguranja kako bi se ona uspešno obavljala kao delatnost. Svaki od elemenata u procesu siguranja ima značajnu 
ulogu, ali su svi oni uslovljeni predmetom osiguranja i učesnicima u osiguranju.

\section{PODELA OSIGURANJA}

Osiguranje je izuzetno široka i kompleksna naučna oblast. U skladu sa tim, podjelu osiguranja nije najjednostavnije izvršiti, a da se pri tome ispoštuju svi željeni parametri i obuhvate sve karakteristike. eke od najčešćih podjela osiguranja ovog tipa su:

1. Podjela osiguranja prema dobrovoljnosti ili načinu nastanka;

2. Podjela osiguranja prema predmetu osiguranja;

3. Podjela osiguranja prema načinu izravnavanja rizika.

Postoje mnogobrojne podjele osiguranja u zavisnosti od kriterijuma na osnovu kojih se mogu izvršiti klasifikacije, međutim osnovna podjela osiguranja jeste na dvije velike grupe, a to su:

1. Životno osiguranje;

2. Neživotno osiguranje [7].

Životno osiguranje je dugoročno osiguranje koje predstavlja jedan od vidova osiguranja lica kojim se pruža socijalna sigurnost pojedincima i njihovim porodicama $\mathrm{i}$ koji se javlja u više oblika i podoblika. Neživotno osiguranje može da bude osiguranje imovine, osiguranje od odgovornosti i osiguranje od nezgode, sa svojim brojnim podvrstama.

\section{OSIGURANJE OD ODGOVORNOSTI I NJEGOV ZNAČAJ}

Osiguranje od odgovornosti predstavlja vrstu osiguranja $u$ kojem se pravno lice osigurava od propusta koji se mogu dogoditi prilikom obavljanja svojih svakodnevnih poslova, a koji mogu da dovedu do materijalne, fininsijske ili druge štete klijenta ili kupca. Ukratko rečeno, postoji određne adgovornost da posao bude realizovan na vrijeme $i$ u skladu sa zaključenim ugovorom, pa se javila potreba da se ugovorne strane osiguraju od nepredviđenih okolnosti.

Osiguranje od odgovornosti se može podijeliti na različite načine, ali kada se posmatra kao cjelina, onda se govori o opštem osiguranju od odgovornosti. Sam pojam opšte odgovornosti je veoma širok, te su i štete koje mogu nastupiti i koje se mogu pripisati nečijoj odogovornosti nebrojene.

Obim opasnosti zavisi, kako od toga da li je riječ o ugostiteljskoj djelatnosti, održavanju puteva, građevinskoj djelatnosti, školi, bolnici ili nekoj drugoj djelatnosti; tako i od mnogih drugih parametara.

Zaključivanjem osiguranja opšte odgovornosti osiguravajuće društvo pruža pravnu i finansijsku zaštitu, kako od posljedica osnovanih, tako i od posljedica neosnovanih odštetnih zahteva. Osiguranjem opšte odgovornosti se osigurava zakonska građanska odgovornost osiguranika za štete usljed smrti, povrede tela ili zdravlja, kao i oštećenja ili uništenja stvari trećeg lica.

Postavlja se pitanje koji su rizici pokriveni ovom vrstom osiguranja. Dakle, pokrivena je odgovornost za štete koje nastanu iz:
1. Poslova i/ili aktivnosti osiguranika;
2. Posedovanja stvari;
3.
4. Pravnog odnosa;

Primjeri rizika koji spadaju u navedenu grupu su sljedeći: odgovornosti iz korišćenja, posedovanja, zakupa ili plodouživanja zemljišta, zgrada i prostorija koje se koriste za obavljanje djelatnosti; odgovornosti iz korištenja objekata koji služe zaposlenima kompanije i slično.

\section{PODELA OSIGURANJA OD ODGOVORNOSTI}

Osiguranje od odgovornosti se može podijeliti u dvije velike grupe, a to su:

\section{Obavezno osiguranje od odgovornosti; \\ 2. Dobrovoljno osiguranje od odgovornosti.}

U obavezna osiguranja od odgovornosti spadaju obavezno osiguranje putnika u javnom saobraćaju od posljedica nesrećnog slučaja, obavezno osiguranje vlasnika motornog vozila od odgovornosti za štetu trećim licima, obavezno osiguranje vlasnika i korisnika vazduhoplova od odgovornosti za štetu pričinjenu trećim licima, obavezno osiguranje plovnih objekata na motorni pogon i priključenih plovila od odgovornosti za štetu pričinjenu trećim licima i na kraju depozit građana kod banaka i drugih finansijskih organizacija. Ugovorom o obaveznom osiguranju od odgovornosti mora biti definisana suma osiguranja, odnosno osigurana suma koja predstavlja najveći iznos obaveze osiguravajućeg društva po štetnom događaju. U dobrovoljna osiguranja od odgovornosti se ubrajaju odgovornosti za štetu koju su na određeni način prouzrokovala različita preduzeća (bilo da su u privatnom ili državnom vlasništvu), gazdinstva, udruženja ili određene institucije.

\section{ANALIZA RAZVIJENOSTI TRŽIŠTA OSIGURANJA U REPUBLICI SRBIJI}

U periodu od 2014. do 2019. godine bitno je istaći da je zabilježen umjeren ali pozitivan rast ekonomske aktivnosti. Rast društvenog bruto proizvoda je bilježio stopu koja se kretala od 2,3\% do 2,5\%. Niske cijene dobara i usluga, niske kamatne stope i izuzetno niska inflacija su doprinjele na dati rast ekonomske aktivnosti, što je naravno imalo uticaja i na tržište osiguranja. U tabeli 1 predstavljeno je kretanje učešća premija životnih i neživotnih osiguranja na tržištu osiguranja $u$ posmatranom periodu:

\begin{tabular}{|l|l|l|}
\hline Godina & $\begin{array}{l}\text { Premija životnog } \\
\text { osiguranja u \% }\end{array}$ & $\begin{array}{l}\text { Premija } \\
\text { neživotnog } \\
\text { osiguranja u \% }\end{array}$ \\
\hline 2014. & 4,80 & 2,50 \\
\hline 2015. & 4,00 & 3,60 \\
\hline 2016. & 5,40 & 2,40 \\
\hline $\mathbf{2 0 1 7}$. & 3,00 & 3,00 \\
\hline $\mathbf{2 0 1 8}$. & 1,60 & 3,30 \\
\hline $\mathbf{2 0 1 9}$. & 2,30 & 2,90 \\
\hline
\end{tabular}

Tabela 1: Kretanje učešća premija životnih $i$ neživotnih osiguranja u period od 2014. do 2019.. godine [8] 
Kao što se u tabeli 1 može vidjeti, premija životnog osiguranja ima najveću tendenciju rasta u 2016. godini, dok je premija neživotnog osiguranja najveću tendenciju rasta imala u 2015. godini. Ono što se takođe može primjetiti da se premija neživotnog osiguranja drži u određenim okvirima bez velikih odstupanja, dok je premija životnog osiguranja imala veće oscilacije.

\section{ANALIZA TRŽIŠTA OSIGURANJA U RAZVIJENIM ZEMLJAMA I UPOREDNA ANALIZA SA TRŽIŠTEM OSIGURANJA U REPUBLICI SRBIJI}

Možemo reći da je na globalnom nivou stanje u periodu od 2015. do 2019. godine bilo stabilno i kretalo se u dobrom smjeru kada se posmatra ekonomska aktivnost. Globalni rast ekonomske aktivnosti je uvijek imao pozitivan trend, a kod preostalih posmatranih veličina se takođe može uočiti preovaldavanje većeg ili manjeg rasta. Ovaj pozitivan trend se može smatrati dobrom osnovom za razvoj tržišta osiguranja. Međutim, različiti regioni su imali različite rezultate kada se posmatraju pojedinačno.

\begin{tabular}{|l|l|l|l|l|}
\hline Godina & \multicolumn{2}{|c|}{ Razvijene zemlje } & \multicolumn{2}{c|}{ Zemlje u razvoju } \\
\hline & $\begin{array}{l}\text { Premija } \\
\text { životnih } \\
\text { osigur. }\end{array}$ & $\begin{array}{l}\text { Premija } \\
\text { neživotn. } \\
\text { osigur. }\end{array}$ & $\begin{array}{l}\text { Premija } \\
\text { životnih } \\
\text { osigur. }\end{array}$ & $\begin{array}{l}\text { Premija } \\
\text { neživ. } \\
\text { osigur. }\end{array}$ \\
\hline 2015. & $+2,5 \%$ & $+2,6 \%$ & $+11,7 \%$ & $+7,8 \%$ \\
\hline 2016. & $+2,0 \%$ & $+1,7 \%$ & $+20,1 \%$ & $+5,3 \%$ \\
\hline 2017. & $+0,2 \%$ & $+2,0 \%$ & $+17,0 \%$ & $+6,0 \%$ \\
\hline 2018. & $+1,7 \%$ & $+2,1 \%$ & $+1,3 \%$ & $+7,8 \%$ \\
\hline 2019. & $+0,5 \%$ & $+2,0 \%$ & $+8,8 \%$ & $+5,8 \%$ \\
\hline
\end{tabular}

Tabela 10: Poređenje kretanja premija životnih $i$ neživotnih osiguranja u razvijenim zemljama i zemljama $u$ razvoju u periodu od 2015. do 2019. godine [9]

Kada razmotrimo podatke iz tabele 10 možemo uočiti da se znatno veći rast kod životnih i kod neživotnih osiguranja javlja kod zemalja u razvoju. Najveći rast premija životnih osiguranja u ovim zemljama je zabilježen $u$ 2016. godini kada je prevazišao $20 \%$. Sa druge strane, najveći rast premija neživotnih osiguranja je dostignut $u$ 2015. i 2018. godini kada je iznoso 7,8\%. Posmatrano globalno, kao što je već rečeno, to što je uočen kontinualan rast je izuzetno dobar pokazatelj. Pored toga, zemlje u razvoju imaju znatno veći prostor za napredovanje, pa je razlika u rastu premije između njih i zemalja koje se smatraju razvijenim logična.

\section{ZAKLJUČAK}

Ono što je nepobitna činjenica sa kojim se danas slaže većina, ako ne i svi stručnjaci iz ove oblasti, a to je da je osiguranje neophodno. Kada su ovo prepoznala osiguravajuća društva u razvijenim zemljama ona su počela naglo da se razvijaju i postavljaju trendove koje osiguravajuća društva iz manje razvijenih zemalja često imaju poteškoću da prate. Danas je za tržište osiguranja i osiguravajuća društva karakteristično korištenje najmo- dernijih tehnologija i najnovijih naučnih ili praktičnih dostignuća.

Tržište osiguranja u Republici Srbiji spada u tržišta u razvoju. Procijenjeno je da domaće tržište ima značajan potencijal koji treba da se iskoristi u bliskoj budućnosti. Podaci različitih istraživanja pokazuju da razvoju sektora osiguranja doprinosi razvoj bankarskog sektora koji se obično razvija prvi. Finansijski sistem Srbije već je godinama unazad bankocentričan: banke su po osnovu dva najznačajnija pokazatelja (bilansna suma i kapital) dominantne za razliku od osiguravajućih kompanija, koje kao institucionalni investitori imaju znatno manji udio na finansijskom tržištu.

Što se tiče konkretno osiguranja od odgovornosti na teritoriji Republike Srbije, možemo da zaključimo da je njegovo trenutno stanje solidno kada se uporedi sa stanjem u regionu i sa stanjem u državama koje se nalaze na istom ili sličnom stepenu razvijenosti. Mađutim, kada se uočeno stanje uporedi sa situacijom u razvijenim zemljama, posebno zemljama EU, može se uočiti da je potrebno ozbiljno raditi na razvoju sektora osiguranja uopšte, pa samim tim i na osiguranju od odgovornosti kao sastavnim dijelom istog. Kako bi se dostigli rezultati koji su standardni za razvijene zemlje potrebno je značajno poraditi na podizanju svijesti stanovništva o potrebama za ovim tipom osiguranja i načinu na koji će se uloga osiguranja predstaviti potenecijalnim klijentima osiguravajućih i povezanih društava.

\section{LITERATURA}

[1] Stević, D. (2013). Osiguranje. Beograd.

[2] Pak, J. Jeremić, L. \& Barjaktarović, L. (2012). Osnovi osiguranja. Beograd.

[3] Miloradić, J. (2006). Osiguranje. Novi Sad.

[4] Čolović, V. (2012). Kontrola rizika i osiguranje. Banja Luka.

[5] Žarković, N. (2008). Ekonomika osiguranja. Beograd.

[6] Stojanović, D. Krstić, M. \& Baduli, L. (2016).

Upravljanje rizikom i osiguranje. Leskovac.

[7] Marović, B. \& Avdalović, V. (2003). Osiguranje $i$ upravljanje rizicima. Novi Sad.

[8] Narodna banka Srbije- izveštaji. (2015-2019). Sektor osiguranja u Republici Srbiji-Izveštaji. Beograd.

[9] Narodna banka Srbije- izveštaji. (2015-2019). Sektor osiguranja u Republici Srbiji- Izveštaji. Beograd.

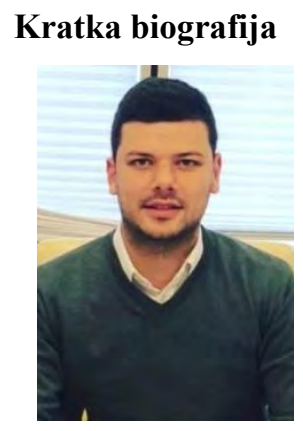

Momčilo Antonić rođen je u Banja Luci 1991. god. Master rad na Fakultetu tehničkih nauka iz oblasti Inženjerskog menadžmenta na temu poslovne inteligencije je odbranilo 2020.godine.

Kontakt:mantonic@venera.ba 